\title{
The Impact of Intellectual Capital on Job Performance based on Faculty Members' Perceptions at Universities
}

\author{
Afaf Abu Zerr ${ }^{1} \&$ Ashraf Aaqoulah ${ }^{2,3}$ \\ ${ }^{1}$ Accounting Department, Business College, Arab Open University, Amman, Jordan \\ ${ }^{2}$ Department of Health Systems Management, College of Public Health and Health Informatics, King Saud bin \\ Abdulaziz University for Health Sciences, Riyadh, Saudi Arabia \\ ${ }^{3}$ King Abdullah International Medical Research Centre (KAIMRC), Riyadh, Saudi Arabia \\ Correspondence: Ashraf Aaqoulah, Department of Health Systems Management, College of Public Health and \\ Health Informatics, King Saud bin Abdulaziz University for Health Sciences, Riyadh, Saudi Arabia.
}

\author{
Received: April 20, 2021 \\ Accepted: May 31, $2021 \quad$ Online Published: June 16, 2021 \\ doi:10.5539/ibr.v14n7p1 \\ URL: https://doi.org/10.5539/ibr.v14n7p1
}

\begin{abstract}
Intellectual capital considers intangible efforts that complete each other. The conversion of efforts and knowledge into valuable assets has come to be known as intellectual capital. This study aims to examine the impact of intellectual capital on the job performance of faculty members at universities. The study used a cross-sectional design. The study population was the academic staff at Jordanian universities. The participants were chosen randomly from different faculties. The study relied on a quantitative method, and the tool for data collection was a questionnaire. The results found that the intellectual capital at universities was high, and the job performance of these universities was also high. In addition, the study found a highly positive impact of intellectual capital on job performance. This study discovers the impact of intellectual capital on the job performance of faculty members at universities. It also draws attention to the importance of intellectual capital in enhancing university performance. This study is useful for decision-makers at universities to maintain their performance and improve the higher-education system in Jordan.
\end{abstract}

Keywords: intellectual capital, job performance, faculty members, universities

\section{Introduction}

Intellectual capital is considered as the main source of innovation and creativity and it accounts for any organisation's success. In addition, it is the catalyst and initiator for the achievements and developments of organisations. This means that organisations must be willing to expend effort in order to attract and obtain intellectual capital and therefore the competitive advantage. Organisations are required to work hard to maintain and develop their services in a technique that differentiates them from other competitors to ensure their continuity and survival (Hussinki, Ritala, Vanhala \& Kianto, 2017).

Intellectual capital has been defined as the hidden value that adds benefit to an organisation (Gupta, Massa, \& Azzopardi, 2016). This is because the intellectual asset is invisible, and also does not appear in the financial statements. In addition, intellectual capital has a significant effect on employee performance, and as a result, it can affect organisational performance (Li, Song, Wang \& Li, 2019) . Intellectual capital can lead to improved performance and can be used as an assessment instrument to create sustainable staff who will be able to meet the future needs of the organisation. Although intellectual capital enhances the quality of services and makes an organisation more competitive, unfortunately, some organisations ignore the importance of human resources because they are not aware that human resources are a component of intellectual capital (Gupta, Massa, \& Azzopardi, 2016).

Many studies have emphasised that organisations need to be superior and creative in their ideas and services. Moreover, they want to provide effective and efficient solutions to address current and future issues in order to attain excellent results through intellectual capital (Obeidat, Tarhini, Masa'deh \& Aqqad, 2017). Decision-makers in organisations need to be aware of business processes, gather accurate information to make correct and practical decisions, adopt or create new procedures and strategies, focus on intellectual capital to achieve successful job performance, develop a sustainable plan to maintain intangible resources, and achieve a 
competitive market share.

Generally, in recent years, intangible assets have been considered a significant source of innovation and development for entities. Many international and national organisations have emphasised the significant role of intangible assets, including; the European Commission, The Organisation for Economic Co-operation and Development (OECD), the World Bank, BNDES in Brazil, and METI in Japan (Bounfour, 2018). According to the OECD (2013), knowledge-based capital accounts for 5\% - $11 \%$ of the Gross Domestic Product (GDP) in many countries, and shows a greater role in the growth of productivity than tangible capital.

Business investment in non-physical assets produces knowledge-based capital (KBC) such as data, software, research and development (R\&D), new organisational processes, patents, specific designs, and skills. Several OECD countries and some non-OECD countries have increased their investment in KBC faster than other investments such as physical capital (equipment, machinery and buildings). Increasing the investment in KBC amplifies the significance of getting human capital policies right, because human capital is considered the basis of KBC. Research in the United States of America mentions that there is a deficit of many analysts and managers with a suitable understanding of the importance of data in business. Business investment in KBC seeks to better align programmers and curricula with the needs of the business. In many countries where educational attainment is already considered high, efforts to improve the quality of education are highly appreciated (Organisation for Economic Co-operation and Development, 2013).

According to popular belief, intellectual capital is associated with the concept of the intangible asset which is normally used by accountants, the knowledge asset concept which is used by economists, and the intellectual capital concept which is used by managers and leaders. However, all of these concepts refer to the intangible worth which is connected to an organisation's employees, customers, management, and other stakeholders. Intellectual capital includes the contents of employees' minds and also the compound intangible structure that surrounds them (Ariff, Islam, \& Van, 2016). Intellectual capital considers intangible efforts that complete each other. The conversion of efforts and knowledge into a valuable asset has come to be known as intellectual capital. Todericiu and Serban (2015) emphasise that intellectual capital considers a group of knowledge assets that are credited to any company or organisation and most considerably support and improve the competitive place of the company or organisation through adding value to defined stakeholders.

Rehman, Chaudhary, Rehman and Zahid (2011) mention that intellectual capital is defined as everything in the organisation that contributes to giving it a competitive advantage. It could be split into a verity of domains such as human capital, intellectual assets, intellectual property, structural capital, and relational capital.

Job performance is an important matter for-profit or non-profit organisation. Even though job performance is an essential factor in business, it is a compound and complicated phenomenon, because it is affected by organisation manager efforts, heterogeneous market conditions, and time. Job performance is the ability of an organisation to meet its goals, customers' needs, and growth in a sustainable manner. An organisation's performance can be affected as a result of the variation of organisation resources including both intangible and tangible resources (Obeidat, Abdallah, Aqqad, Akhoershiedah \& Maqableh, 2016). Consequently, enhancing job performance does not merely rely on the effective placement of tangible resources but also on intangible resources such as knowledge management and employee behaviour. In universities, job performance includes educational performance, behaviours at the university, scientific research, and community service. These components lead to achieving university goals and objectives.

It is required from Jordanian universities to maintain innovation rates and sustain links with the workplace, and continually improve human resources management. Therefore, universities are required to adopt intellectual capital approaches to improve job performance. Universities should measure their performance in improving the higher-education system. They need to continuously regenerate themselves through the intelligent use of knowledge management. Intellectual capital could create a large positive effect if universities use it in an appropriate manner because it offers better opportunities for universities to achieve their objectives. Therefore, this study aims to examine the impact of intellectual capital on the job performance of faculty members at Jordanian universities.

\section{Literature Review}

Organisations have started to focus on intellectual capital since the early 1980s because they have realised that it plays an essential role in maximising the organization's profit (F-Jardón \& Martos, 2009). The intellectual capital concept comes from a study of the relationship between invisible assets and performance (Sherif \& Elsayed, 2016). 
The period of the eighties until the beginning of the nineties of the twentieth century is characterised by a group of opinions and proposals which focused on the importance and role of intangible assets in achieving corporate growth, increasing returns, and ensuring continuity, which directed attention towards human capabilities (innovation and creativity, and generating new ideas, products, and services) (Abu Zerr, 2020).

Marr, Gray and Neely (2003) provided five reasons for measuring intellectual capital. These reasons are: It helps organisations to adjust their strategies; it enables diversification and expansion decisions to be made; it helps to assess the implementation of strategies; it enables the identification of norms related to intellectual capital to stakeholders; and the results of intellectual capital measurement can be used as a basis for service compensation. Researchers have suggested many models in the context of classifying intellectual capital components, but there is no universal classification for intellectual capital components (Chahal \& Bakshi, 2016, Sharabati, Jawad \& Bontis, 2010, Pourkiani, Sheikhy \& Daroneh, 2014). For example, Bontis (2001) initially referred to three components which were human, structural, and customer capital, and then modified the categories to relational capital, human capital, structural capital, and intellectual assets. Intangible goods are assets that can be maintained, merchandised, and represented appropriately, including; trademarks, copyright, and technical knowledge. Intangible competencies refer to distinct and separate issues of competitive advantage that differentiate an organisation from others. It includes structural competencies, innovation competencies, and human resources. Obeidat and his colleagues (2016) mentioned that intellectual capital includes three categories, which are structural capital, human capital, and relational capital.

Nikolaichuk, Arkhypenko and Matukova-Yaryha (2019) generalises the conditions and essence of company value estimates and proves the intellectual capital influence on its value, and the presentation of the subsystem of intellectual capital of the company and its components are substantiated. The algorithm of appraisal of the performance of the management subsystem on the grounds of a matrix model using cost aspects and structure is proposed. A study by Li et al., (2019) explored the relationship between knowledge sharing, intellectual capital, and innovation performance of construction enterprises and the mediating effect of knowledge sharing on the relationship between innovation performance and intellectual capital. Li et al. also mentioned that the era of the knowledge economy is driven by innovation, based on the input of intangible assets which play a crucial role in the long-term development of organisations. The product value of any enterprise is broadly determined by its intellectual capital. Thus, as the scientists of China's economy, construction enterprises must support their investments in intellectual capital, and evolve their competitiveness in the market.

Iazzolino, Migliano and Guarnaccia (2019) focused on a new methodology for assessing the market value of enterprises (Quantitative Intellectual Capital) that studies intellectual capital (IC) as a vital factor which influences the overall value. Velayutham and Rahman (2018) examined the relationship between academic employees and their salaries. The analyses performed pointed out a positive correlation between academic human capital and their salaries. Zeb, Abdullah and Javaid (2018) analysed the relationship between human capital management (which includes selection, recruitment, training and development), employee job performance, and performance appraisal in the telecom sector of Pakistan. To discover the influence of human capital management practices on the job performance of employees, a study of Asiaei and Jusoh (2015) analysed the contribution of intellectual capital in enhancing firm performance in Tehran. They emphasise on relational capital, social capital, human capital, and structural capital. They found that human capital, relational capital and structural capital, are significant to bringing about a positive impact on a organisations' performance. However, the study failed to find the contribution of social capital in driving firm performance.

Further studies have been conducted on intellectual capital. Sharabati, Radi, Nour, Durra, and Moghrabi (2013) conducted a study to assess and analyse the intellectual capital for tourism office performance. The study found a positive relationship between intellectual capital and the performance of tourist offices in Jordan. In another study, Ahangar (2011) examined the effectiveness of intellectual capital on performance. The study discovered that there is a significant positive relationship between intellectual capital and performance. Moreover, Yadiati (2019) examined the effect of intellectual capital of green relational capital, green social capital, and green human capital on an organisation's environmental performance. The results found that green intellectual capital and organisational reputation positively affected environmental performance. Ramírez (2013) analysed the intellectual importance of capital management to face the challenges in European universities. Ramírez provides assistance in enabling universities to identify and manage their intangible assets. Al-Dujaili (2012) examined the effectiveness of intellectual capital on organisational creativity. The study results indicated that there is a strong positive relationship between the effectiveness of intellectual capital and organisational creativity. Handzic and Öztürk (2010) mentioned that there is a common recognition of intellectual capital importance as the main source of competitive advantage for different enterprises operating in today's knowledge economy. Specifically, 
universities are recognised as being crucial to the economy as transmitters of knowledge and the prime producers in society. Thus, the management and measurement of intellectual capital by universities is becoming an increasingly essential matter in knowledge management practice and research. The authors argued that universities need to use intellectual capital as a tool to aid them in facing management challenges and diffuse their activities and intangible resources to their stakeholders and society. Cuozzo, Dumay, Palmaccio and Lombardi, R. (2017) found that there is a lack of significant innovation and research in the evolution of intellectual capital disclosure. Studies focused on general issues that rely on the reports of European companies. in addition, there are insufficient studies investigated intellectual capital disclosure in countries around the world, nor the organisational level to examine intellectual capital disclosure.

This study reviews previous studies about the relationship between intellectual capital and performance. However, there is no prior study that examined the relationship between intellectual capital and performance at universities from academic staff members' perspectives. Therefore, this study is going to examine this relationship at universities. In addition, in this study, the intellectual capital domains have been modified to be more suitable to achieve the aims of this study. Hence, based on the above literature, the present study hypothesises that:

Intellectual capital has a positive impact on the job performance of faculty members at Jordanian universities.

The main hypothesis has been divided into sub-hypotheses:

Sub-Hypothesis No. 1: Human capital has a positive impact on job performance of faculty members at Jordanian universities.

Sub-Hypothesis No. 2: Intellectual assets have a positive impact on job performance of faculty members at Jordanian universities.

Sub-Hypothesis No. 3: Intellectual property has a positive impact on job performance of faculty members at Jordanian universities.

Sub-Hypothesis No. 4: Structural capital has a positive impact on job performance of faculty members at Jordanian universities.

Sub-Hypothesis No. 5: Relational capital has a positive impact on job performance of faculty members at Jordanian universities.

The independent and dependent variables of the hypothesised model are presented along with their domains in the following form:

\begin{tabular}{|c|c|}
\hline Independent Variables & \multicolumn{1}{c}{ Dependent Variables } \\
\hline Intellectual Capital & Job Performance \\
\hline Human Capital & Educational Performance \\
\hline Intellectual Assets & Behaviors at the University \\
\hline Intellectual property & Scientific Research \\
\hline Structural Capital & Community Service \\
\hline Relational Capital & \\
\hline
\end{tabular}

Figure 1. the hypothesized model

\section{Methodology}

The study used a cross-sectional design. The study population was the academic staff at Jordanian universities. The participants were chosen randomly from different faculties. The academic staff had different ranks such as lecturers, assistant professors, associated professors, and professors. They worked in different departments and faculties such as the faculty of administrative and financial sciences, the faculty of law, and the faculty of literature. The majority of the staff were $\mathrm{PhD}$ holders.

The questionnaire was distributed at six universities. Two of these universities were public and four were private. The number of questionnaires that were distributed was 600, and the number of returned questionnaires was 398 . The response rate was $66 \%$. This study used a quantitative method (cross-sectional survey) to investigate the impact of intellectual capital on the job performance of faculty members at Jordanian universities, and the 
questionnaire was developed by the researcher. In this study, a series of statements about intellectual capital concepts was derived from various studies. The questionnaire has 34 statements about intellectual capital.

The study relied on a questionnaire for data collection. The questionnaire was built based on the literature and was divided into three sections. The first section includes the demographic variables of participants such as gender, age, country of certificate, faculty, academic rank and experience. The second section has five domains and 34 items related to intellectual capital. The domains of intellectual capital were human capital, intellectual assets, intellectual property, structural capital, and relational capital. The third section has four domains with 21 items related to job performance. The job performance domains were educational performance, behaviours at the university, scientific research, and community service. The answers for the second and third sections were based on a 5-point Likert scale. The response options were from 1 (Strongly Disagree) to 5 (Strongly Agree). The statements for the second and third sections were made up of positive and negative statements. For validity, face validity and content validity were conducted on the questionnaire. The questionnaire was sent to $\mathrm{PhD}$ holders so they could provide feedback about the questionnaire and how the researcher could improve it to be more suitable and accurate. The questionnaire was modified based on comments from the $\mathrm{PhD}$ holders.

For a pilot study, the questionnaire was distributed randomly among faculty staff at two universities (public and private universities). The pilot study was conducted in Jordan in November 2019. The purpose of the pilot study was to assess the reliability of the questionnaire, receive comments about the questionnaire statements, and give a good sense of how the study procedures worked in practice. The data collected in the pilot study was subjected to reliability analysis. The analyses showed a Cronbach's alpha value of 0.81 , and therefore, the questionnaire was considered a reliable tool.

The data from the survey was entered directly into the Statistical Program for Social Sciences (IBM SPSS) for analysis. Before the analysis, coding for the negatively worded items of the questionnaire was reversed, and mean values for items were computed. The data analysis firstly provides basic descriptive information on the distribution of selected demographic data (frequency, percentage, mean, and standard deviation), followed by the items referring to intellectual capital. To examine the impact of intellectual capital on the job performance of faculty members at Jordanian universities, the linear regression test was performed.

\section{Results}

The results showed the characteristics of the study participants. In addition, it showed the mean and standard deviation of the intellectual capital domains and items. Furthermore, the results show the mean and standard deviation of job performance domains and items. Finally, the impact of intellectual capital on job performance was calculated.

Table 1 shows the frequencies and characteristics of participants. According to gender, there are nearly three times as many male participants to female participants. $74.4 \%$ of the participants were male and $25.4 \%$ were female. Based on the county of the certificate, more than half of the participants graduated from Arabic countries $(60.1 \%)$. According to age group, most of the participants were between 40 - > 50 years old $(40.7 \%$.) More than half of the participants belong to the faculty of administrative and financial sciences at $54.3 \%$. Based on the academic rank, the majority of participants were assistant professors (58.8\%), and based on experience, nearly half of the participants had between 6 to 10 years of experience (49\%).

Table 1. Characteristics of the study participants

\begin{tabular}{llcc}
\hline Characteristics & Groups & Count & $\%$ \\
\hline Gender & Male & 297 & 74.4 \\
& Female & 101 & 25.4 \\
\hline Country of Certificate & Arabic Country & 239 & 60.1 \\
& Native English Speaking Country & 56 & 14.1 \\
& Western European Country & 62 & 15.6 \\
& Eastern European Country & 41 & 10.3 \\
\hline Age & $<40$ years old & 145 & 36.4 \\
& $40-<$ 50 years old & 162 & 40.7 \\
& $50-<60$ years old & 54 & 13.6 \\
\hline Faculty & 60 years old or more & 37 & 9.3 \\
& Administrative and Financial Sciences & 216 & 54.3 \\
& Law & 11 & 2.8 \\
& Engineering & 23 & 5.8 \\
& Literature & 62 & 15.6
\end{tabular}




\begin{tabular}{llcc} 
& Nursing & 15 & 3.8 \\
& Sciences & 15 & 8.0 \\
& Medicine & 32 & 4.5 \\
\hline Academic Rank & Instructor & 18 & 19.3 \\
& Assistant Professor & 77 & 58.8 \\
& Associated Professor & 234 & 18.1 \\
& Professor & 72 & 3.8 \\
\hline Work experience & $<5$ years & 15 & 23.4 \\
& $6-10$ years & 93 & 49.0 \\
& $11-15$ years & 195 & 22.4 \\
& $>15$ years & 89 & 5.3 \\
\hline
\end{tabular}

The results of Table 2 show the mean and standard deviation of intellectual capital domains and items. The first domain was human capital which consists of six items. The item 'Faculty members have the ability and enough knowledge to simplify information for students' achieved the highest mean (mean= 4.08), with a standard deviation of 0.93 . The second domain was intellectual assets, which also consisted of six items. The item 'Faculty members should have a profile where student scores, activities, and research is kept' achieved the highest mean (mean= 4.07), with a standard deviation of 0.83 . The third domain was intellectual property. This consisted of five items. The item 'The university has a portfolio of intellectual property' had the highest mean (mean $=4.11$ ), with a standard deviation of 0.72 . The fourth domain was structural capital, which consisted of nine items. The item 'There is a strong Internet network at the university' had the highest mean (mean= 4.14), with a standard deviation of 0.86 . The fifth domain was relational capital, which consisted of eight items. The item 'There is active cooperation and communication (meetings, seminars, conferences, and arbitration projects) among different faculty members at the university' had the highest mean (mean= 3.98), with a standard deviation of 0.90 .

Table 2. Mean and standard deviation of intellectual capital domains and items

\begin{tabular}{|c|c|c|c|}
\hline Domains & Intellectual Capital Items & Mean & SD \\
\hline \multirow{6}{*}{ 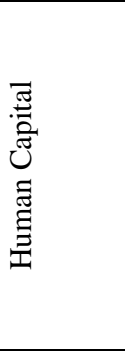 } & Faculty members have different nationalities. & 4.07 & 0.88 \\
\hline & Faculty members hold certificates from Arab and foreign universities. & 4.00 & 1.05 \\
\hline & $\begin{array}{l}\text { Faculty members have the ability to use different methods of teaching such as using } \\
\text { books, references, assignments for students, educational materials from the Internet, and } \\
\text { power points. }\end{array}$ & 4.05 & 0.88 \\
\hline & $\begin{array}{l}\text { Faculty members have the ability and enough knowledge to simplify information for } \\
\text { students. }\end{array}$ & 4.08 & 0.93 \\
\hline & Faculty members have sufficient teaching skills to simplify information for students. & 3.51 & 1.01 \\
\hline & $\begin{array}{l}\text { Faculty members encourage students to be creative by providing new ideas and } \\
\text { applications. }\end{array}$ & 3.81 & 1.09 \\
\hline \multirow{6}{*}{ 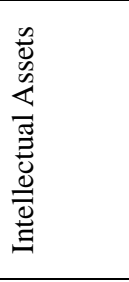 } & Regulations and instructions of the university are passed to faculty members. & 3.86 & 0.94 \\
\hline & $\begin{array}{l}\text { Faculty members should have a profile where student scores, activities, and research is } \\
\text { kept. }\end{array}$ & 4.07 & .083 \\
\hline & $\begin{array}{l}\text { Faculty members use official letters effectively in administrative and academic } \\
\text { processes. }\end{array}$ & 3.75 & 1.02 \\
\hline & All external and internal leaflets and letters are passed to faculty members. & 3.77 & 1.00 \\
\hline & Software programs on the computers of faculty members, are updated continuously. & 3.45 & 1.15 \\
\hline & The faculty member's file contains all of the activities during the semester. & 3.36 & 1.05 \\
\hline \multirow{5}{*}{ 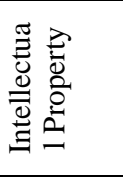 } & The university owns formally registered intellectual property. & 3.78 & 1.09 \\
\hline & The university has a portfolio of intellectual property & 4.11 & 0.72 \\
\hline & The university does marketing for its intellectual property. & 4.00 & 0.65 \\
\hline & The university programmes have the ability to attract students. & 3.91 & 0.80 \\
\hline & Faculty members publish at least two papers every three years. & 3.86 & 0.76 \\
\hline \multirow{8}{*}{ 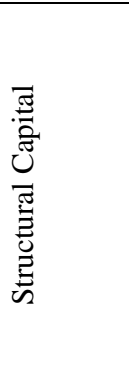 } & $\begin{array}{l}\text { The university has an effective program to achieve the objectives of the academic } \\
\text { program. }\end{array}$ & 3.84 & 0.88 \\
\hline & $\begin{array}{l}\text { The university has an effective database and software for various disciplines and can be } \\
\text { used by students and faculty members. }\end{array}$ & 3.62 & 1.06 \\
\hline & There is a strong Internet network at the university. & 4.14 & 0.86 \\
\hline & The teaching load for faculty member is fair. & 4.08 & 0.82 \\
\hline & Lecture times are suitable for faculty members and students. & 4.01 & 0.81 \\
\hline & $\begin{array}{l}\text { The work environment is conformable regarding scientific atmosphere, squares, field and } \\
\text { trees. }\end{array}$ & 3.82 & 0.88 \\
\hline & The library contains valuable books. & 3.79 & 0.96 \\
\hline & The library contains new books. & 3.99 & 0.94 \\
\hline
\end{tabular}


Faculty members are satisfied about research databases that are available at the $3.94 \quad 0.85$ university.

There is active cooperation and communication (meetings, seminars, conferences and arbitration projects) among different faculty members at the university.

$\begin{array}{lll}\text { There is active cooperation and communication (meetings, seminars, conferences and } & 3.91 & 0.95 \\ \text { arbitration projects) among different department members at the same faculty. } & 3.73 & 0.92 \\ \text { The university has a good reputation at the local level. } & 3.73 & 0.88 \\ \text { There is cooperation between the university and other local universities. } & 3.52 & 0.91 \\ \text { There is collaboration between the university and universities from different countries. } & 3.32 & 1.03 \\ \text { The university provides assistance, financial aid and material support to the local } & 3.21 & 1.16 \\ \text { community. } & 3.36 & 1.08 \\ \text { The university gives priority in recruitment to people who live nearby to the university. } & 3.80 & 0.49 \\ \text { The university takes into account the acceptance of people with special needs. } & \text { All items } & \end{array}$

The results of table 3 show the mean and standard deviation of job performance domains and items. The first domain was educational performance. It consists of six items. The item 'Faculty members do their work in an effective and efficient manner' had the highest mean (mean= 4.24), with standard deviation 0.80 . The second domain was behaviours at the university, which consists of five items. The items 'Faculty members have a commitment to lecture time' and 'There is a cooperative relationship between faculty members' both had the highest mean (mean $=4.16$ for both items), with standard deviations of 0.85 and 0.84 respectively. The third domain was scientific research, which consisted of six items. The item 'Faculty members conduct studies and scientific research consistently' had the highest mean (mean= 3.89), with a standard deviation of 0.93 . The last domain was community service. It consists of four items. The item 'Faculty members participate in solving community problems' had the highest mean (mean $=4.01$ ), with a standard deviation 0.90 . The mean for all items was 3.87 with a standard deviation 0.44 .

Table 3. Mean and standard deviation of job performance domains and items

\begin{tabular}{llcc}
\hline Domains & \multicolumn{1}{c}{ Job Performance Items } & Mean & SD \\
\hline & Faculty members are familiar with work information. & 3.92 & 1.08 \\
& Faculty members do their work in an effective and efficient manner. & 4.24 & 0.80 \\
& Faculty members do their work accurately. & 4.17 & 0.82 \\
& Faculty members initiate new and significant ideas. & 4.03 & 0.70 \\
& Faculty members are committed to completing the syllabus on time. & 3.84 & 0.78 \\
& Faculty members use different methods for teaching. & 3.67 & 0.93 \\
\hline & Faculty members have a commitment to lecture time. & 4.16 & 0.85 \\
& There is a cooperative relationship between faculty members. & 4.16 & 0.84 \\
& Faculty members apply work rules and procedures accurately. & 4.02 & 0.85 \\
& The relationship between faculty members and students is formal. & 3.86 & 1.03 \\
& Faculty members participate in solving department and faculty problems. & 3.62 & 1.00 \\
\hline & Faculty members conduct studies and scientific research consistently. & 3.89 & 0.93 \\
& Faculty members rely on up to date references. & 3.86 & 0.98 \\
& Faculty members attend conferences and seminars. & 3.63 & 1.00 \\
& Faculty members attend workshops to develop their performance. & 3.60 & 1.01 \\
& Faculty members are willing to do scientific research. & 3.76 & 0.83 \\
& Faculty members read professional scientific research continuously. & 3.54 & 0.96 \\
\hline & Faculty members cooperate with the local community service associations. & 3.90 & 1.00 \\
& Faculty members provide free lectures to the local community. & 3.97 & 0.95 \\
& Faculty members provide free training courses to the local community. & 4.00 & 099 \\
& Faculty members participate in solving community problems. & 4.01 & 0.90 \\
\hline & & 3.87 & 0.44 \\
\hline
\end{tabular}

\subsection{Test of Hypotheses}

The study hypotheses have been developed and tested as follows. The study examined the main hypothesis, which states: "Intellectual capital has a positive impact on the job performance of faculty members at Jordanian universities."

Table 4 shows the impact of intellectual capital on job performance. Multiple linear regression analysis was performed, which confirmed that there is a positive high impact of intellectual capital on job performance (Correlation Coefficient $(\mathrm{R})=0.69$ ). Also, the study concludes that the independent variable (intellectual capital) interprets $48 \%$ of the variance in the dependent variable $(\mathrm{R} 2=0.48)$, which means that the regression equation 
predicted almost a $48 \%$ contribution of intellectual capital to job performance in the faculty members at Jordanian universities. In addition, the models' respective $F$, and beta coefficient scores were significant $(\mathrm{F}=363.60, \beta=0.69, \mathrm{p}=0.00)$, therefore, the impact of intellectual capital on job performance is highly significant.

Table 4. The impact of intellectual capital on job performance

\begin{tabular}{ccccccc}
\hline & \multicolumn{5}{c}{ Job Performance } \\
\hline \multirow{2}{*}{ Intellectual Capital } & $\mathrm{R}$ & $\mathrm{R}^{2}$ & $\mathrm{~B}$ & Beta $(\beta)$ & $\mathrm{F}$ & Sig $(\mathrm{F})$ \\
& 0.69 & 0.48 & 0.77 & 0.69 & 363.60 & 0.00 \\
\hline
\end{tabular}

Sub-Hypothesis No. 1: "Human Capital has a positive impact on the job performance of faculty members at Jordanian universities". Table 5 shows the impact of Human Capital on job performance.

Table 5. The impact of Human Capital on job performance

\begin{tabular}{lcccccc}
\hline & \multicolumn{7}{c}{ Job Performance } \\
\hline \multirow{2}{*}{ Human Capital } & $\mathrm{R}$ & $\mathrm{R}^{2}$ & $\mathrm{~B}$ & Beta $(\beta)$ & $\mathrm{F}$ & Sig $(\mathrm{F})$ \\
& 0.53 & 0.28 & 0.51 & 0.53 & 155.54 & 0.00 \\
\hline
\end{tabular}

Sub-Hypothesis No. 2: "Intellectual Assets have a positive impact on the job performance of faculty members at Jordanian universities". Table 6 shows the impact of Intellectual Assets on job performance.

Table 6. The impact of Intellectual Assets on job performance

\begin{tabular}{ccccccc}
\hline & \multicolumn{7}{c}{ Job Performance } \\
\hline \multirow{2}{*}{ Intellectual Assets } & $\mathrm{R}$ & $\mathrm{R}^{2}$ & $\mathrm{~B}$ & Beta $(\beta)$ & $\mathrm{F}$ & Sig $(\mathrm{F})$ \\
& 0.37 & 0.13 & 0.36 & 0.37 & 60.86 & 0.00 \\
\hline
\end{tabular}

Hypothesis No. 3: "Intellectual Property has a positive impact on the job performance of faculty members at Jordanian universities". Table 7 shows the impact of Intellectual Property on job performance.

Table 7. The impact of Intellectual Property on job performance

\begin{tabular}{lcccccc}
\hline & \multicolumn{7}{c}{ Job Performance } \\
\hline \multirow{2}{*}{ Intellectual Property } & $\mathrm{R}$ & $\mathrm{R}^{2}$ & $\mathrm{~B}$ & Beta $(\beta)$ & $\mathrm{F}$ & Sig (F) \\
& 0.43 & 0.19 & 0.33 & 0.43 & 91.30 & 0.00 \\
\hline
\end{tabular}

Hypothesis No. 4: "Structural Capital has a positive impact on the job performance of faculty members at Jordanian universities". Table 8 shows the impact of Structural Capital on job performance.

Table 8. The impact of Structural Capital on job performance

\begin{tabular}{lcccccc}
\hline & \multicolumn{7}{c}{ Job Performance } \\
\hline \multirow{2}{*}{ Structural Capital } & $\mathrm{R}$ & $\mathrm{R}^{2}$ & $\mathrm{~B}$ & Beta $(\beta)$ & $\mathrm{F}$ & Sig $(\mathrm{F})$ \\
& 0.54 & 0.29 & 0.42 & 0.54 & 164.21 & 0.00 \\
\hline
\end{tabular}

Hypothesis No. 5: "Relational Capital has a positive impact on the job performance of faculty members at Jordanian universities". Table (9) shows the impact of Relational Capital on job performance.

Table 9. The impact of Relational Capital on job performance

\begin{tabular}{lcccccc}
\hline & \multicolumn{7}{c}{ Job Performance } \\
\hline \multirow{2}{*}{ Relational Capital } & $\mathrm{R}$ & $\mathrm{R}^{2}$ & $\mathrm{~B}$ & Beta $(\beta)$ & $\mathrm{F}$ & Sig $(\mathrm{F})$ \\
& 0.60 & 0.36 & 0.46 & 0.60 & 225.45 & 0.00 \\
\hline
\end{tabular}




\section{Discussion}

This study aimed to examine the impact of intellectual capital on the job performance of faculty members at Jordanian universities. The intellectual capital and job performance at Jordanian universities in this study were high. In addition, the study found a highly positive impact of intellectual capital on job performance.

The study results are consistent with other studies that also found a positive correlation between intellectual capital and job performance (Sharabati, et al., 2013; Wanjala; 2013; Al-Dujaili, 2012 \& Ahangar, 2011).

Since Jordanian universities require maintaining and making improvements in the productivity of intellectual capital, this can assist Jordanian universities to move to the top rank in the Middle East area. The measurement of university performance is essential for the higher-education system in Jordan. Intellectual capital considers a competitive advantage for universities. The academic staff who work in these universities that motivate intellectual capital do their best to develop the learning process and its outcomes. Intellectual capital is considered a hidden treasure that needs to be extracted for existence and practice. It is also considered to be a wealth factor for any organisation (Todericiu \& Serban, 2015). Cabrita and Bontis (2008) showed that there are different domains from which intellectual capital is comprised. Furthermore, intellectual capital has a direct impact on job performance. Adam and Urquhart (2009) mentioned that both cognitive and intellectual capital have a positive influence in service sectors. There are other researchers who supported the relationship between intellectual capital and performance such as Sundać and Fatur (2009). Ahangar (2011) confirmed that human intellect key to intellectual capital, and creates value-added efficiency and increases the efficiency of an organisation to be profitable. Using intellectual capital is considered significant in enhancing organisational profitability and performance. Managerial practices that utilise intellectual capital create more success through the organisation's inputs, which leads to better performance. These studies were consistent with this current study.

Nevertheless, there are some studies that were conducted to investigate the relationship between intellectual capital and job performance which found a negative impact or no relation between these two concepts. Moreover, Kamath (2008) examined the relationship between intellectual capital and job performance and found no relationship between them. The explanation for these finding could be because there are some factors that could directly or indirectly effect the relationship between intellectual capital and job performance negatively. In the study of Handzic and Öztürk (2010), discoveries for human capital demonstrate a generally positive picture. These discoveries uncover that there is an all-inclusive acknowledgment of the significance. This is a significant and empowering finding. Interestingly, the discoveries for structural capital are isolated. Despite the fact that there is a far-reaching affirmation of its significance, the dispersion of current outcomes suggests a somewhat negative general judgment of the structural capital at present. Significant inadequacies have been distinguished in the territories of (i) specialty research domains and scholarly contributions; and (ii) supporting information technology and library infrastructure and services. The first problem is reinforced by comments on teaching overload and the lack of necessary time and opportunities to conduct and present research.

Ramírez (2013) examined intellectual capital European colleges. The investigation characterises the means to build up a model of intellectual capital administration at colleges. In this sense, an important beginning stage would be the definition and diffusion of enterprises' vital targets. At that point, basic intangibles identified with these goals ought to be distinguished and the causal system of the relationship among them ought to be set up. Finally, an intermittent review of the model to adjust to new difficulties ought to be completed.

Despite the essential theoretical and practical implications, the study also has a few limitations that need to be discussed, and further study is recommended in the future. Firstly, the study relied on a cross-sectional research design; and research in the future needs to use interviews to gain in-depth data regarding intellectual capital and its effect on performance. Secondly, this study only explores the effect of intellectual capital on performance at universities from academic staff members; however, future studies need to focus on this effect from the perspective of senior managers and the deans of faculties. New studies need to be concentrated on these factors to obtain more information and a comprehensive understanding of the impact of intellectual capital on job performance.

\section{Conclusion}

In conclusion, intellectual capital is a significant factor in enhancing the performance of universities. Therefore, Jordanian universities need to pay attention to intellectual capital to maintain their performance and improve the higher-education system in Jordan. Intellectual capital increases growth and improves the effectiveness and efficiencies of universities. It improves the image of universities in the education industry. Universities that adopt intellectual capital can utilise their tangible and intangible resources to compete with other universities.

The improvement of the components of intellectual capital (human capital domain, intellectual assets domain, 
intellectual property domain, structural capital domain, and relational capital domain) support the development of university performance. Universities should allocate enough budget to maintain their intellectual capital. In addition, human resources in universities need to receive orientation and training to utilise the facilities and infrastructure available in their universities. This makes the academic staff more active and cooperative in different areas such as research activities.

\section{References}

Abu Zerr, A. E. (2020). Accounting Measurement and Recognition of Intellectual Capital. Accountants Journal, 27(83), 10-15.

Adam, M. S., \& Urquhart, C. (2009). No man is an island: Social and human capital in IT capacity building in the Maldives. Information and Organization, 19(1), 1-21. https://doi.org/10.1016/j.infoandorg.2007.11.002

Ahangar, R. G. (2011). The relationship between intellectual capital and financial performance: An empirical investigation in an Iranian company. African journal of business management, 5(1), 88-95.

Al-Dujaili, M. A. A. (2012). Influence of intellectual capital in the organizational Innovation. International Journal of Innovation, Management and Technology, 3(2), 128-135.

Ariff, A. H. M., Islam, A., \& van Zijl, T. (2016). Intellectual capital and market performance: The case of multinational R\&D firms in the US. The journal of developing areas, 50(5), 487-495. https://doi.org/10.1353/jda.2016.0052

Asiaei, K., \& Jusoh, R. (2015). A multidimensional view of intellectual capital: the impact on organizational performance. Management Decision, 53(3), 668-697. https://doi.org/10.1108/MD-05-2014-0300

Bontis, N. (2001). Assessing knowledge assets: a review of the models used to measure intellectual capital. International journal of management reviews, 3(1), 41-60. https://doi.org/10.1111/1468-2370.00053

Bounfour, A. (2018). Africa: the next frontier for intellectual capital?. Journal of Intellectual Capital, 19(3), 474-479. https://doi.org/10.1108/JIC-12-2017-0167

Cabrita, M. D. R., \& Bontis, N. (2008). Intellectual capital and business performance in the Portuguese banking industry. International Journal of Technology Management, 43(1-3), 212-237. https://doi.org/10.1504/IJTM.2008.019416

Chahal, H., \& Bakshi, P. (2016). Measurement of intellectual capital in the Indian banking sector. Vikalpa, 4l(1), 61-73. https://doi.org/10.1177/0256090916629253

Cuozzo, B., Dumay, J., Palmaccio, M., \& Lombardi, R. (2017). Intellectual capital disclosure: a structured literature review. Journal of Intellectual Capital, 18(1), 9-28. https://doi.org/10.1108/JIC-10-2016-0104

F-Jardón, C. M., \& Martos, M. S. (2009). Intellectual capital and performance in wood industries of Argentina. Journal of Intellectual Capital, 10(1), 600-616. https://doi.org/10.1108/14691930910996670

Gupta, U. G., Massa, N. P., \& Azzopardi, J. (2016). Culture and intellectual capital: towards a conceptual framework. International journal of organizational analysis, 24(3), 438-453. https://doi.org/10.1108/IJOA-06-2015-0871

Handzic, M., \& Öztürk, E. (2010). University Intellectual Capital: Measurement Model and Application. 2nd International Symposium on Sustainable Development, Sarajevo, 740-747.

Hussinki, H., Ritala, P., Vanhala, M., \& Kianto, A. (2017). Intellectual capital, knowledge management practices and firm performance. Journal of Intellectual Capital, 18(4), 904-922. https://doi.org/10.1108/JIC-11-2016-0116

Iazzolino, G., Migliano, G., \& Guarnaccia, N. (2019). The QuIC: Quantitative intellectual capital-based methodology for firm valuation. TEM Journal, 8(2), 525-537. https://doi.org/10.18421/TEM82-28

Kamath, G. B. (2008). Intellectual capital and corporate performance in Indian pharmaceutical industry. Journal of Intellectual Capital, 9(4), 684-704. https://doi.org/10.1108/14691930810913221

Li, Y., Song, Y., Wang, J., \& Li, C. (2019). Intellectual capital, knowledge sharing, and innovation performance: Evidence from the Chinese construction industry. Sustainability, 11(9), 2713. https://doi.org/10.3390/su11092713

Marr, B., Gray, D., \& Neely, A. (2003). Why do firms measure their intellectual capital? Journal of intellectual capital, 4(4), 441-464. https://doi.org/10.1108/14691930310504509 
Nikolaichuk, O., Arkhypenko, S., \& Matukova-Yaryha, D. (2019). Intellectual capital management as a composite value of corporate enterprise in a global economy. ESPACIOS, 40(16).

Obeidat, B. Y., Abdallah, A. B., Aqqad, N. O., Akhoershiedah, A. H. O. M., \& Maqableh, M. (2016). The effect of intellectual capital on organizational performance: The mediating role of knowledge sharing. Communications and Network, 9(1), 1-27. https://doi.org/10.4236/cn.2017.91001

Obeidat, B. Y., Tarhini, A., Masa'deh, R. E., \& Aqqad, N. O. (2017). The impact of intellectual capital on innovation via the mediating role of knowledge management: a structural equation modelling approach. International Journal of Knowledge Management Studies, 8(3-4), 273-298. https://doi.org/10.1504/IJKMS.2017.087071

Organisation for Economic Co-operation and Development (2013). New Sources of Growth: Knowledge-Based Capital Key Analyses and Policy. Synthesis Report May 2013. Retrieved from https://www.oecd.org/sti/inno/knowledge-based-capital-synthesis.pdf

Pourkiani, M., Sheikhy, A., \& Daroneh, M. S. (2014). Importance and status of intellectual capital in knowledge economy. Indian Journal of fundamental and Applied life Sciences, 4(4), 512-518.

Ramírez, C. Y. (2013). Intellectual capital management and reporting in European higher education institutions. Intangible Capital, 9(1), 1-19. https://doi.org/10.3926/ic.201

Rehman, W. U., Chaudhary, A. R., Rehman, H. U., \& Zahid, A. (2011). Intellectual capital performance and its impact on corporate performance: An empirical evidence from MODARABA sector of Pakistan. Australian journal of business and management research, 1(5), 8.

Sharabati, A. A. A., Jawad, S. N., \& Bontis, N. (2010). Intellectual capital and business performance in the pharmaceutical sector of Jordan. Management decision, 48(1), 105-31. https://doi.org/10.1108/00251741011014481

Sharabati, A. A. A., Radi, A. R. K., Nour, A. N. I., Durra, A. B. I., \& Moghrabi, K. M. (2013). The effect of intellectual capital on Jordanian tourism sector's business performance. American Journal of Business and Management, 2(3), 210-221. https://doi.org/10.11634/216796061302370

Sherif, M., \& Elsayed, M. (2016). The impact of intellectual capital on corporate performance: Evidence from the Egyptian insurance market. International Journal of Innovation Management, 20(3), 1650034. https://doi.org/10.1142/S1363919616500341

Sundać, D., \& Fatur, I. (2009). Measurement and management of intellectual capital. Tourism and Hospitality Management, 15(2), 279-290.

Todericiu, R., \& Șerban, A. (2015). The Assesment of Intellectual Capital in Romanian Universities. Studies in Business and Economics, 10(3), 100-110. https://doi.org/10.1515/sbe-2015-0040

Velayutham, A., \& Rahman, A. R. (2018). The value of human capital within Canadian business schools. Journal of Intellectual Capital. 19(4), 836-855. https://doi.org/10.1108/JIC-06-2017-0086

Wanjala, J. W. (2013). To assess the effect of intellectual capital on organizational performance in the manufacturing sector. International Journal of Research in Commerce, IT \& management, 3(12), 113-118.

Yadiati, W. (2019). The role of green intellectual capital and organizational reputation in influencing environmental performance. International Journal of Energy Economics and Policy, 9(3), 261-268. https://doi.org/10.32479/ijeep.7752

Zeb, A., Abdullah, N. H., \& Javaid, M. (2018). Impact of human capital management practices on employees' job performance. Journal of Physics: Conference Series, 1049(1), 012020. https://doi.org/10.1088/1742-6596/1049/1/012020

\section{Copyrights}

Copyright for this article is retained by the author(s), with first publication rights granted to the journal.

This is an open-access article distributed under the terms and conditions of the Creative Commons Attribution license (http://creativecommons.org/licenses/by/4.0/). 